\title{
Evaluation of laboratory parameters in inflammatory myositis
}

\section{Inflamatuar miyozitte laboratuvar parametrelerinin değerlendirilmesi}

\author{
Melih PAMUKCU' $\square$, Tugba IZCI DURAN²*
}

${ }^{1}$ Health Sciences University, Dışkapı Education and Research Hospital, Clinic of Rheumatology, Ankara, TURKEY ${ }^{2}$ Ondokuz Mayıs University, Medical Faculty, Department of Internal Medicine, Division of Rheumatology, Samsun/TURKEY

\begin{abstract}
Aim: Polymyositis (PM) and dermatomyositis (DM) are the two most common forms of idiopathic inflammatory myositis (IIM) and they are generally rare diseases. We aimed to investigate the parameter that can help the diagnosis with easy and cheap laboratory tests as C-reactive protein (CRP)/albumin ratio (CAR), neutrophil/lymphocyte ratio (NLR), platelet/ lymphocyte ratio (PLR).
\end{abstract}

Material and Methods: A total of 60 participants; 30 patients ( 19 females, 11 males) and 30 healthy volunteers (16 females, 14 males) aged $>18$ years were included in this retrospective study. Demographic data (age, gender) and CRP, erythrocyte sedimentation rate (ESR), albumin values, leukocyte, neutrophil, lymphocyte, and platelet counts were recorded.

Results: $50 \%$ of the patients had a diagnosis of DM and $50 \%$ of them had a diagnosis of PM, and the median (IQR) duration of disease was 4 (0.5-13) years. The median (IQR) age of the patients was 46 (38-60) years and healthy volunteers was 45 (42-52) years $(p=0.506)$. Gender distributions, creatinine levels, leukocyte and platelet counts were similar in the patient and control groups ( $p>0.005)$. The median values of CAR (3.6 (1.0-5.1) vs. $0.3(0.1-0.6), p<0.001), N L R(3.4(2.3-4.4)$ vs. 1.8 (1.6-2.1), $p=0.002)$, and PLR (223 (157-249) vs. 107 (100-125), $p=0.040$ ) were found to be significantly high in the patient group.

Conclusion: Given the positive association between the disease and CAR, CAR can be considered as a helpful assessment tool to show inflammation in patients with suspected IIM.

Keywords: Idiopathic inflammatory myopathies; C-reactive protein; inflammation; lymphocytes; neutrophils

Corresponding Author*: Tugba Izci Duran, Ondokuz Mayıs University, Medical Faculty, Department of Internal Medicine, Division of Rheumatology, Samsun/TURKEY

E-mail: drtugbaizciduran@gmail.com

ORCID: 0000-0003-4428-9873

Recevied: 04.06.2021 accepted: 20.08.2021

Doi: $10.18663 /$ tjcl.947989 


\section{Öz}

Amaç: Polimiyozit (PM) ve dermatomiyozit (DM), idiyopatik inflamatuar miyozitin (iiM) en sık görülen iki formudur ve genellikle nadir görülen hastalıklardır. Bu hastalıklarda C-reaktif protein (CRP)/albümin oranı (CAR), nötrofil/lenfosit oranı (NLR), trombosit/ lenfosit oranı (PLR) gibi tanıya yardımcı olabilecek kolay ve ucuz laboratuvar parametrelerini araştırmayı amaçladık.

Gereç ve Yöntemler: 18 yaş üstü 30 hasta (19 kadın, 11 erkek) ve 30 sağlıklı gönüllü (16 kadın, 14 erkek) olmak üzere toplam 60 katılımcı bu retrospektif çalışmaya dahil edildi. Demografik veriler (yaş, cinsiyet) ve CRP, eritrosit sedimantasyon hızı (ESR), albümin değerleri, lökosit, nötrofil, lenfosit ve trombosit sayıları kaydedildi.

Bulgular: Hastaların \%50'sinin DM, \%50'sinin PM tanısı vardı ve ortanca (IQR) hastalık süresi 4 (0,5-13) yıldı. Hastaların medyan (IQR) yaşı 46 (38-60) yıl ve sağlıklı gönüllülerin 45 (42-52) yıl idi ( $p=0,506)$. Hasta ve kontrol grubunda cinsiyet dağılımları, kreatinin düzeyleri, lökosit ve trombosit sayıları benzerdi $(p>0,005)$. CAR $(3,6(1,0-5,1)$ vs. $0,3(0,1-0,6)$, p<0,001), $\operatorname{NLR}(3,4(2,3-4,4)$ vs. $1,8(1,6-2,1), \mathrm{p}=0,002)$ ve PLR (223 (157-249) vs. $107(100-125), \mathrm{p}=0,040)$ ortanca değerleri hasta grubunda anlamlı olarak yüksek bulundu.

Sonuç: Hastalık ve CAR arasındaki pozitif ilişki göz önüne alındığında, CAR, IIM şüphesi olan hastalarda inflamasyonu göstermek için yararlı bir değerlendirme aracı olarak düşünülebilir.

Anahtar Kelimeler: İdiyopatik inflamatuar miyopatiler; C-reaktif protein; inflamasyon; lenfositler; nötrofiller

\section{Introduction}

Polymyositis (PM) and dermatomyositis (DM) are the two most common forms of idiopathic inflammatory myositis (IIM) and they are generally rare diseases [1]. IIM have a reported incidence of 0.1 to 1 per 100000 person-years and prevalence of 0.55 to 6 per 100000 in the United States [1]. They are characterized by symmetrical proximal muscle weakness, myopathy findings on electromyography (EMG), increased muscle enzyme in serum, necrosis findings with mononuclear cell infiltration in the muscles DM is differentiated from PM with its typical cutaneous findings [2].

In older series, the 5-year survival rate of IIM patients was less than $50 \%$. In recent studies showed that improved survival of IIM patients, ranging from $72 \%$ to $85 \%, 34 \%$ to $75 \%$, and $42 \%$ to $85 \%$ at 2, 5 and 10 years, respectively [3-19]. Despite all kinds of developments, mortality of IIM patients is 2-3 times higher compared to the healthy population [20]. Advanced age, delay in diagnosis or treatment, cancer-related myositis, and extramuscular organ involvement including the lung have been reported as poor prognosis factors [20-22]. In some studies, it has been reported that serum IL-6 levels and some autoantibodies specific to myositis (for example, anti-nuclear matrix protein-2, anti-transcriptional mediator factor $1-\gamma$, and anti-melanoma differentiation-associated gene-5), may be biomarkers that can be used to predict poor prognosis [23]. These reported myositisspecific antibodies cannot be easily measured in clinical practice, and a valuable and simple prognostic biomarker has not yet been developed for patients with IIM.

Recent studies have reported that $C$ reactive protein (CRP)/ albumin ratio (CAR), neutrophil/lymphocyte ratio (NLR), and platelet/lymphocyte ratio (PLR) are useful and cost-effective prognostic markers in many diseases [24-26]. CAR, NLR, and PLR have been reported as inflammatory markers that can show disease activity and increase in inflammation in rheumatic diseases, including IIM [27-32]. In this study, by comparing the rates of NLR, PLR, CAR at the time of diagnosis in patients diagnosed with IIM and with healthy volunteers, besides the steps of expensive and time-consuming examinations such as autoantibody examinations, magnetic resonance imaging (MRI), muscle biopsy and EMG required for the diagnosis of IIM, it was aimed to investigate the parameter that can help the diagnosis with easy and cheap laboratory tests.

\section{Material and Methods}

Thirty patients were included in this retrospective study who applied to the rheumatology clinic between January 2020 and January 2021 and diagnosed with IIM according to the 2017 European League Against Rheumatism/American College of Rheumatology classification criteria for adult and juvenile idiopathic inflammatory myopathies [33]. And 30 healthy volunteers with matching age and gender were included in this study. The patients with malignancy, pregnancy, breastfeeding, and other chronic diseases were excluded. 
Demographic data (age, gender), habits (smoking, alcohol), used drugs and previous disease history of the patients with IIM at the time of diagnosis, EMG, MRI and muscle biopsy were recorded. The values of CRP $(\mathrm{mg} / \mathrm{dL})$, erythrocyte sedimentation rate (ESR) ( $\mathrm{mm} /$ hour), albumin $(\mathrm{g} / \mathrm{dL})$, creatine phosphokinase (CPK) (U/L) were obtained from biochemical analysis. Leukocyte $(\mathrm{K} / \mathrm{uL})$, neutrophil $(\mathrm{K} / \mathrm{uL})$, lymphocyte $(\mathrm{K} / \mathrm{uL})$, thrombocyte $(\mathrm{K} / \mathrm{uL})$ numbers were obtained from hemogram analysis. The CAR value was obtained by dividing the CRP value by the albumin value, the NLR value was obtained by dividing the neutrophil number by the lymphocyte number, and the PLR value was obtained by dividing the platelet number by the lymphocyte value. They were compared with the results of healthy volunteers with matching age and gender.

The study protocol was approved by the local ethics committee (Approval number: 2021/19). Written informed consent was obtained from each patient and the study was conducted in accordance with the Helsinki Declaration principles.

\section{Statistical analysis}

SPSS (Statistical Package for Social Sciences) version 22.0 program was used for statistical analysis in the evaluation of the data. Categorical variables were presented as number (percentage). The distribution characteristics of continuous variables were evaluated by using the Kolmogorov-Smirnov test. While data conforming to normal distribution were presented as mean \pm standard deviation (SD), data not conforming to normal distribution were presented as median (IQR). Chi-square test was used to compare categorical data. In comparison of continuous variables, Independent-Samples T test or Mann-Whitney U test was preferred according to the distribution feature. A $p<0.05$ was considered as statistically significant.

\section{Results}

A total of 60 participants; 30 patients (19 females, 11 males) and 30 healthy volunteers (16 females, 14 males) were included in the study and the median (IQR) age of the patients was 46 (38-60) years; the median age of healthy volunteers was 45 (42-52) years, the groups were statistically similar ( $p>$ 0.05). $50 \%$ of the patients had a diagnosis of DM and $50 \%$ of them had a diagnosis of PM, and the median (IQR) duration of disease was 4 (0.5-13) years.

The demographic data and laboratory values of the patients and the control group are summarized in Table-1. Median ages, gender distributions, creatinine levels, WBC and platelet counts were similar in the patient and control groups. Albumin and lymphocyte counts were significantly lower in the IIM group compared to the control group, while CPK level, neutrophil count, NLR, PLR, CAR, ESR and CRP levels were significantly higher in the IIM group compared to the healthy control group.

\begin{tabular}{|c|c|c|c|}
\hline \multicolumn{4}{|c|}{$\begin{array}{l}\text { Table-1: Demographic and laboratory data of PM/DM pa- } \\
\text { tients and the control group }\end{array}$} \\
\hline Parameters & IIM (n:30) & $\begin{array}{l}\text { Control group } \\
\quad(n: 31)\end{array}$ & P value \\
\hline Age, year & $46(38-60)$ & $45(42-52)$ & 0.506 \\
\hline Female gender, $\mathrm{n}(\%)$ & $19(63 \%)$ & $16(51 \%)$ & 0.440 \\
\hline \multicolumn{4}{|c|}{ Laboratory parameters } \\
\hline Creatine, $\mathrm{mg} / \mathrm{dL}$ & $0.62(0.48-0.81)$ & $0.77(0.7-0.88)$ & 0.008 \\
\hline Albumin, $\mathrm{g} / \mathrm{dL}$ & $4.1(4.0-4.6)$ & $4.8(4.7-4.9)$ & $<0.001$ \\
\hline $\begin{array}{l}\text { Creatine phospho- } \\
\text { kinase, u/L }\end{array}$ & $361(102-1253)$ & $59(44-80)$ & $<0.001$ \\
\hline Hemoglobin, g/dL & $13.1(12.3-13.7)$ & $14.8(13.8-15.7)$ & $<0.001$ \\
\hline 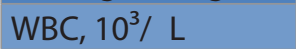 & $7.3(6.2-9.3)$ & $7.1(6.3-8.7)$ & 0.829 \\
\hline Neutrophil, $10^{3} / \otimes L$ & $4.8(4.0-6.9)$ & $3.9(3.5-4.7)$ & 0.005 \\
\hline Lymphocyte, $10^{3} / \mathbb{\mathrm { L }}$ & $1.8(0.6-3.7)$ & $2.2(1.0-3.2)$ & 0.028 \\
\hline Platelet, $10^{3} / \mathbb{\otimes L}$ & $274(246-380)$ & $243(216-284)$ & 0.051 \\
\hline $\begin{array}{l}\text { Neutrophil/lym- } \\
\text { phocyte ratio }\end{array}$ & $3.4(2.3-4.4)$ & $1.8(1.6-2.1)$ & 0.002 \\
\hline $\begin{array}{l}\text { Platelet/lympho- } \\
\text { cyte ratio }\end{array}$ & 223 (157-249) & $107(100-125)$ & 0.040 \\
\hline CRP/albumin ratio & $3.6(1.0-5.1)$ & $0.3(0.1-0.6)$ & $<0.001$ \\
\hline ESR, mm/hour & $20.5(8-29.5)$ & $4.0(3-7)$ & $<0.001$ \\
\hline $\mathrm{CRP}, \mathrm{mg} / \mathrm{L}$ & $6.5(2.5-15.6)$ & $1.7(0.7-2.8)$ & $<0.001$ \\
\hline
\end{tabular}

\section{Discussion}

Idiopathic inflammatory myositis, of which PM and DM constitute the majority, are illnesses which are rarely-seen and have generally poor prognosis [2]. The malignancy relationship of DM has been clearly defined [2]. More recent studies have reported 5-year survival rate of patients with IIM is $70-96 \%$ [20]. This rate is significantly higher compared to the period 30-40 years ago, when patients had difficulty in early diagnosis, and when immunosuppressive drugs were not as developed as now [4, 20, 33, 34]. Delays in diagnosis and treatment are factors that affect the prognosis negatively $[20,21]$. So, it is important to diagnose and start treatment quickly in the IIM disease group. CAR, NLR and PLR are named among the prognostic scores based on inflammation [35]. We compared these values, which are indicators of inflammation, with the control group at the time of diagnosis of patients with IIM, and we aimed to investigate their benefits at the stage of diagnosis. According to our findings, while CAR, NLR and PLR 
values were significantly higher in patients diagnosed with IIM compared to the control group. In addition, hemoglobin and albumin were significantly lower, CPK, ESR and CRP levels were significantly higher in the patient group.

Neutrophil/lymphocyte ratio is a value for which the data is obtained from the hemogram measurement, which is easily performed in every clinic. Studies have shown that NLR is associated with the disease activity of systemic autoimmune diseases [27-29, 36]. Recently, through the study conducted by Gao MZ et al. and Yang W et al., it was reported that NLR was associated with disease activity in patients with IIM and interstitial lung disease dependent on DM [31, 32]. In our study, like the significant relationship reported in these studies, significant difference was found between the NLR in newly diagnosed IIM patients.

C-reactive protein/albumin ratio value has been found to be high in many rheumatic diseases, including systemic lupus erythematosus and rheumatoid arthritis, malignant diseases and patients treated in the intensive care unit [24-32]. Yang et al. reported that CAR has a correlation with DAS-28 in RA patients and that CAR can be used as an indicator to evaluate the activity of RA disease [30]. Similarly, in the study conducted by Sunar et al., it was reported that there is a positive but weak correlation between CAR and DAS28-ESR and ESR [35]. In a retrospective study, Akkecceci et al. showed that CAR was found to be significantly associated with CRP, and ESR levels and disease activity in Takayasu arteritis [37]. In a study involving patients with ANCA-associated vasculitis, it was reported that CAR at diagnosis was an independent predictor of all-cause mortality [38]. Similar to studies conducted with other inflammatory diseases, in this study, the CAR values of the patients diagnosed with IIM at the time of diagnosis were found to be significantly higher than the control group.

There is a need for markers that can be used in the diagnosis stage and in determining the prognosis in IIM patients, which are simple, easily accessible and capable of giving fast results. The results of examinations such as muscle enzymes, autoantibody tests, EMG, MRI, and biopsy, which are still used during diagnosis, take time and some of them require invasive procedures. Further studies are required to identify such markers which are easy-to-apply, giving results quickly and inexpensive.

There are some limitations in this study. The first one is that the sample is relatively small and it is a single center study. Second, selection bias may arise because it is a retrospective study.
Finally, we did not evaluate the effects of treatment on CAR.

\section{Conclusion}

The CAR values of the patients with IIM at the time of diagnosis were significantly higher than the healthy group. Given the positive association between the disease and CAR, CAR can be considered as a helpful assessment tool to show inflammation in patients with suspected IIM. Further studies are needed to determine the use of CAR in patients with IIM.

\section{Declaration of conflicting interests}

The authors declared no conflicts of interest with respect to the authorship and/or publication of this article.

\section{References}

1. Furst D.E., et al., Epidemiology of adult idiopathic inflammatory myopathies in a U.S. managed care plan. Muscle Nerve, 2012; 45:676-83.

2. HaY.J., et al., Baseline peripheral blood neutrophil-to-lymphocyte ratio could predict survival in patients with adult polymyositis and dermatomyositis: A retrospective observational study. PLoS One, 2018; 1: 0190411.

3. Marie I., et al., Polymyositis and dermatomyositis: short term and longterm outcome, and predictive factors of prognosis. J Rheumatol, 2001; 28: 2230-7.

4. Airio A, H. Kautiainen, and M. Hakala, Prognosis and mortality of polymyositis and dermatomyositis patients. Clin Rheumatol, 2006; 25: 234-9.

5. Benbassat, J., et al. Prognostic factors in polymyositis/ dermatomyositis. A computer-assisted analysis of ninety-two cases. Arthritis Rheum, 1985; 28: 249-55.

6. BOHAN, A., et al., A COMPUTER-ASSISTED ANALYSIS OF 153 PATIENTS WITH POLYMYOSITIS AND DERMATOMYOSITIS. Medicine, 1977; 56: 255-86.

7. Carpenter, J.R., et al., Survival in polymyositis: corticosteroids and risk factors. J Rheumatol, 1977; 4: 207-14.

8. DeVere, R. and W.G. Bradley. Polymyositis: its presentation, morbidity and mortality. Brain, 1975; 98: 637-66.

9. Dankó, K., et al. Long-Term Survival of Patients With Idiopathic Inflammatory Myopathies According to Clinical Features: A Longitudinal Study of 162 Cases. Medicine, 2004; 83: 35-42.

10. Henriksson, K.G. and P. Sandstedt .Polymyositis-treatment and prognosis. A study of 107 patients. Acta Neurol Scand, 1982; 65: 280-300.

11. Hochberg, M.C., D. Lopez-Acuna, and A.M. Gittelsohn, Mortality from polymyositis and dermatomyositis in the United States, 1968-1978. Arthritis Rheum, 1983; 26: 1465-71. 
12. Lynn, S.J., et al., Adult-onset inflammatory myopathy: North Canterbury experience 1989-2001. Internal Medicine Journal, 2005; 35: 170-3.

13. Mustafa, K.N. and S.S. Dahbour, Clinical characteristics and outcomes of patients with idiopathic inflammatory myopathies from Jordan 1996-2009. Clin Rheumatol, 2010; 29: 1381-5.

14. Schiopu, E., et al., Predictors of survival in a cohort of patients with polymyositis and dermatomyositis: effect of corticosteroids, methotrexate and azathioprine. Arthritis Research \& Therapy, 2012; 14: 22

15. Torres, C., et al., Survival, mortality and causes of death in inflammatory myopathies. Autoimmunity, 2006; 39: 205-15.

16. Yamasaki, Y., et al., Longterm survival and associated risk factors in patients with adult-onset idiopathic inflammatory myopathies and amyopathic dermatomyositis: experience in a single institute in Japan. J Rheumatol, 2011; 38: 1636-43.

17. Yu, K.H., et al., Survival analysis of patients with dermatomyositis and polymyositis: analysis of 192 Chinese cases. Clin Rheumatol 2011; 30: 1595-601.

18. Uthman, I., D. Vázquez-Abad, and J.L. Senécal, Distinctive features of idiopathic inflammatory myopathies in French Canadians. Semin Arthritis Rheum, 1996; 26: 447-58.

19. Maugars, Y.M., et al., Long-term prognosis of 69 patients with dermatomyositis or polymyositis. Clin Exp Rheumatol, 1996; 14: 263-74.

20. Marie, I., Morbidity and mortality in adult polymyositis and dermatomyositis. Curr Rheumatol Rep, 2012; 14: 275-85.

21. Dalakas, M.C., Inflammatory muscle diseases. N Engl J Med, 2015; 372: 1734-47.

22. Salvador, F.B. and D.A. Isenberg, Outcome predictors in patients with idiopathic inflammatory myopathies. Clin Exp Rheumatol, 2012; 30: 980

23. Lu, X., Q. Peng, and G. Wang, Discovery of new biomarkers of idiopathic inflammatory myopathy. Clin Chim Acta, 2015; 444: $117-25$.

24. Templeton, A.J., et al., Prognostic role of neutrophil-tolymphocyte ratio in solid tumors: a systematic review and metaanalysis. J Natl Cancer Inst, 2014; 106: 124.

25. Xu, X.L., et al., A Novel Inflammation-Based Prognostic Score, the C-Reactive Protein/Albumin Ratio Predicts the Prognosis of Patients with Operable Esophageal Squamous Cell Carcinoma. PLoS One, 2015; 10: 0138657.
26. Ishizuka, M., et al., Clinical Significance of the C-Reactive Protein to Albumin Ratio for Survival After Surgery for Colorectal Cancer. Ann Surg Oncol, 2016; 23: 900-7.

27. Rifaioglu, E.N., et al., Neutrophil to lymphocyte ratio in Behçet's disease as a marker of disease activity. Acta Dermatovenerol Alp Pannonica Adriat, 2014; 23: 65-7.

28. Uslu, A.U., et al., Two new inflammatory markers associated with Disease Activity Score-28 in patients with rheumatoid arthritis: neutrophil-lymphocyte ratio and platelet-lymphocyte ratio. Int J Rheum Dis, 2015; 18: 731-5.

29. Qin, B., et al., Neutrophil to lymphocyte ratio (NLR) and platelet to lymphocyte ratio (PLR) were useful markers in assessment of inflammatory response and disease activity in SLE patients. Mod Rheumatol, 2016; 26: 372-6.

30. Peng, Y.F., et al., Platelet to Lymphocyte Ratio in Polymyositis as a Marker of Disease Activity. Clin Lab, 2016; 62; 915-9.

31. Gao, M.Z., et al., Red blood cell distribution width and neutrophil to lymphocyte ratio are correlated with disease activity of dermatomyositis and polymyositis. J Clin Lab Anal, 2018; 32.

32. Yang, W., et al., Neutrophil-lymphocyte ratio and plateletlymphocyte ratio are 2 new inflammatory markers associated with pulmonary involvement and disease activity in patients with dermatomyositis. Clin Chim Acta, 2017; 465: 11-6.

33. Medsger, T.A., Jr., H. Robinson, and A.T. Masi, Factors affecting survivorship in polymyositis. A life-table study of 124 patients. Arthritis Rheum, 1971; 14: 249-58.

34. Limaye, V., et al., Mortality and its predominant causes in a large cohort of patients with biopsy-determined inflammatory myositis. Intern Med J, 2012; 42: 191-8.

35. Sunar, İ. and Ş. Ataman, Serum C-Reactive Protein/Albumin Ratio in Rheumatoid Arthritis and its Relationship With Disease Activity, Physical Function, and Quality of Life. 2020; 35: 247-53.

36. Absenger, G., et al., A derived neutrophil to lymphocyte ratio predicts clinical outcome in stage II and III colon cancer patients. Br J Cancer, 2013; 109: 395-400.

37. Seringec Akkececi, N., et al., The C-Reactive Protein/Albumin Ratio and Complete Blood Count Parameters as Indicators of Disease Activity in Patients with Takayasu Arteritis. Med Sci Monit, 2019; 25: 1401-09.

38. Moon, J.S., et al., C-Reactive Protein to Serum Albumin Ratio Is an Independent Predictor of All-Cause Mortality in Patients with ANCA-Associated Vasculitis. 2018; 59: 865-71. 